\title{
ENVIRONMENTAL COMPLAINTS IN AVEIRO, PORTUGAL: ACTORS, CONCERNS, TERRITORIAL PATTERN, AND RESOLUTIONS
}

\author{
Reclamações ambientais em Aveiro, Portugal: \\ atores, preocupações, padrão territorial e resoluções
}

Daniela Salgado Carvalho PhD Student of Environmental Sciences

University of Aveiro

Aveiro - Portugal danielasalgado@ua.pt

Teresa Fidélis

Professor of Department of the Environment and Planning

University of Aveiro

Aveiro - Portugal

teresafidelis@ua.pt

Artigo recebido para publicação em 18/09/2008 e aceito para publicação em 28/01/2009

\begin{abstract}
This paper presents an environmental diagnosis based on public complaints on environmental issues submitted to the Environmental Department of the Aveiro City Council, Portugal, between 2000 and 2005. It discusses the potential influences of these in local environmental planning and governance. The paper has been organised into five sections. The first of these introduces the study. The second section focuses on the conceptual approaches relating to environmental grassroots movements, the main actors involved in these movements and the role played by local government. It also contains a brief review of the most recent urban environmental quality challenges in the European context together with a description of the main features of the associated political and legal framework in Portugal. The third section describes the case study and the methodology used. The results of the empirical study are detailed in the fourth section. The final section critically analyses these results with emphases on the temporal evolution of the submission of complaints, the actors involved, the local environmental problems and their associated spatial pattern as well as the responses given by the City Council. This information may then be used to provide a useful indicator for the perception of environmental quality as well as a credible instrument for the visualisation and evaluation of local performance in terms of environmental planning and management.
\end{abstract}

Keywords: Environmental complaints. Public perception. Environmental concerns. Environmental quality.

RESUMO: Este artigo apresenta os principais resultados de um diagnóstico ambiental desenvolvido a partir das reclamações em matéria de ambiente submetidas à Divisão de Ambiente da Câmara Municipal de Aveiro, entre os anos de 2000 e 2005. O artigo está estruturado em cinco partes. A primeira apresenta o estudo desenvolvido. Na segunda, são evidenciados os aspectos 
Environmental complaints in Aveiro, Portugal: actors, concerns, territorial pattern, and resolutions Daniela Salgado Carvalho, Teresa Fidélis

conceituais pertinentes aos movimentos ambientais de raiz popular, aos principais atores envolvidos nesses movimentos e ao papel desempenhado pela governação local. Os mais recentes desafios para a promoção da qualidade ambiental no contexto Europeu, assim como as principais características dos quadros político e legal associados em Portugal são sumarizados. A terceira parte apresenta a metodologia adotada. Subseqüentemente, expõemse os resultados do estudo empírico. Finalmente, a última parte traz uma análise crítica dos resultados obtidos, salientando a evolução temporal da apresentação de reclamações, os atores envolvidos, os problemas ambientais locais e o padrão territorial associado, bem como as respostas proporcionadas pela câmara municipal, resultando, assim, em uma ferramenta útil para visualizar e avaliar a evolução da percepção ambiental e a intervenção da governação local em termos de planejamento e gestão ambiental.

Palavras-chave: Reclamações ambientais. Percepção pública. Preocupações ambientais. Qualidade ambiental.

\section{Introduction}

The environmental problems resulting from urbanization processes have become an increasing focus for the attention of populations, organizations and governmental authorities in general. Air pollution, noise, and poor urban solid waste management are common examples of the environmental problems to be found in urban areas. Due to the fact that environmental quality is intrinsically related to quality of life, public health and even environmental sustainability (see, for example, VAN KAMP, LEIDELMEIJER et al., 2003 and PACIONE, 2003), the resolution of quality-related problems is increasingly associated with approaches to local management, planning and governance.

The increase in the public's understanding of environmental issues, and the consequent demand for higher urban environmental quality standards, have acted, together with other factors, to mobilise public complaints over local governments (CARVALHO and FIDÉLIS, 2007, p. 83).

The existence of environmental problems, the public's perception of the environment and the increasing demands made in this regard, allow for an analysis of the thematic pattern of the related complaints submitted to local authorities, who are accountable for the maintenance and improvement of local, publically-owned resources as well as compliance with environmental regulations (CARVALHO and FIDÉLIS, 2007, p. 83).

These complaints may constitute a relevant medium for the characterisation and evaluation of the public's environmental concerns. Taken together with the responses given by local authorities, as measured against expectations, the perception of environmental quality within the study area may be identified. In addition, and as previously proposed by Dasgupta and Wheeler (1997, p. 15), "the complaints process undoubtedly provides some useful monitoring information, and an important avenue for community participation in environmental policy".

The interpretation of this type of data enables the construction of environmental maps, in which the triangular relationship of "citizens - environment and territory - local governance" can be assessed.

In an effort to pursue this important, but little explored, area of research, the objective of the study summarized in this article was to identify what the environmental complaints submitted to local governments reveal about the perception of environmental quality in urban and periurban areas, the spatial pattern of such concerns within the study

Sociedade \& Natureza, Uberlândia, 21 (1): 51-70, ABR. 2009 
area, the diversity of actors involved, and the nature of the intervention of local government in the resolution of complaints and their associated environmental problems.

In this study, developed under an MSc Programme, complaints about environmental problems submitted to the local authorities are considered to be formal and non-organized comments and demands which can be seen as direct consequences of the perception and subsequent reaction to environmental problems and acting as a manifestation of the protection of a subjective right.

Based on this information, a diagnosis of the perception of environmental quality in the municipality of Aveiro was developed. The complaints were used as indicators for the proposed analysis. The complaints themselves had their origins in the dissatisfaction of, and inconvenience caused to, local actors (citizens and institutions amongst others) in respect of the environmental problems found in the municipality.

\section{Conceptual approaches}

The theoretical framework for formal public complaints on environmental problems at the local level has not been widely reported in the literature. It has been, however, widely discussed in terms of grassroots movements (see KOUSIS, 2001; KOUSIS, 2007), particularly when covered by the label NIMBY (Not In My Back Yard) (see FIGUEIREDO, FIDÉLIS et al., 2001). The framework has been fully described as it applies to those NIMBY-expressed motivations and attitudes that have instigated public protest at the local level (see, for example, KRAFT and CLARY, 1991; HUNTER and LEYDEN, 1995; MARTÍNCRESPO, 1996; ELLIOTT, 1998; RICHMAN, 2001; JAMISON, 2003; and SCHIVELY, 2007).

Despite the fact that the complaints about environmental matters analyzed in this study do not originate from organized grassroots movements, the NIMBY orientation is relevant since the complaints mostly refer to unpleasant situations resulting from local sources of problems (CARVALHO and
FIDÉLIS, 2007, p. 83). Nevertheless, we have included the incidences of local environmental protests since one of the objects of the study involves the complaints about local environmental problems, as they are perceived and protested against by local actors.

Cantrell (1980) proposed a method for the investigation of environmental complaints which encompasses a definition of their types. According to this author, people are "most concerned with complaints involving nuisances", which means that the expression of a concern, through the submission of a complaint, usually involves dissatisfaction. Although most complaints are nuisance-related, other types, having political, social or even sympathetic and personal motivations, were also identified (CANTRELL, 1980, p. 1).

The recent interest in the study of protests made by local and non-organized movements (FIGUEIREDO and FIDÉLIS, 2003, p. 3) as well as the strictly local nature seen in these cases (KOUSIS, 2001, p. 132; FIGUEIREDO and FIDÉLIS, 2003, p. 2), have resulted in some difficulties in the setting up of a profile of the environmental issues which are the object of protest.

Figueiredo and Fidélis (2003) have made important suggestions concerning those environmental problems which generated a considerable number of environmental grassroots movements in Portugal between 1974 and 1994. The most significant of these are waste collection and treatment, the construction or infrastructures, industrial activities, and natural areas.

Kousis (2001), in a study into environmental conflicts in Southern Europe, did not specify which issues engendered large numbers of movements or conflicts but did highlight construction activities, land transport, traffic, military installations, tourism activities, and environmental policies as the main focus of protests in urban areas. In an effort to explore the political dimension of local environmental protest in Greece through an analysis of newspaper data and 
public agency archives, Kousis (2007) highlighted claims relating to waste, sewage and agriculture or animal husbandry problems as being the main concerns found in the public archival data set, and claims relating to activities that intrude on wildlife, manufacturing and energy installations in the case of the media.

A study carried out by Cantrell (1980), who analyzed the environmental complaints submitted to the Prince William County Health Department in Virginia, revealed the types of complaints submitted between 1973 and 1979. Over the period covered by this study, the complaints focused on refuse, sewage, pests, and animals. Other types of nuisances identified were related, in decreasing order, to water, food, air pollution, housing, weed and swimming facilities. Dasgupta and Wheeler (1997) proposed that complaints made by the public should be used as environmental indicators in assessing the role of the public in China's pollution control system. Over a two year period, the public's complaints mostly related to air, water and noise pollution and were concentrated in urban and industrial centres.

Given that the case studies analyzed here are not based on environmental movements, but on individual protests, the difficulty in setting up the previously mentioned profile becomes more evident. However, these studies provide important indications about the general panorama of the main environmental concerns in the study areas in question, particularly as they relate to non-organized movements, as well as the submission of complaints analyzed here.

A range of actors can be identified as being involved in the protests concerning environmental problems. In this sense, and as mentioned by Parker (1997, p. 73), "the positions of actors are continually shifting, being reformulated and re-expressed in response to changing circumstances".

These may either have some accountability for the contested environmental damage or be part of the required and resulting decision-making processes. In this sense, the performance of local government, which plays an important preventative and interventional role in these matters, is of major significance. Nevertheless, as stated by Esengun, Sayili et al. (2006, p. 635), "successful solutions to environmental problems can only be achieved by not only governmental intervention and enforceable regulations, but also through participation of the whole society".

In this study, the local actors involved in the protests relating to environmental problems were found to be of three types: those who complained, those responsible for causing the problems and those responsible for their resolution. Other similar studies, local in scope and limited to a specific geographical area, have also found that a wide range of actors are involved (see KOUSIS, 2001; KOUSIS, 2007; FIGUEIREDO et al., 2001).

In terms of grassroots movements, Kousis (2001) identified a number of different local actors. These included residents, local governments, local environmental groups, labour and trade unions, cultural activity clubs, and representatives of political parties. In addition to identifying the actors involved, Kousis (2001) emphasized that these tend to be concentrated in more developed urban areas and in the form of more heterogeneous and representative groups (see also KOUSIS, 2007).

As for the actors involved in the resolution of these conflicts, the author highlighted the role played by state bodies (e.g. ministries, central government, national parliament), sub-state bodies (e.g. regional government and local government), the courts, the European Union (e.g. the European Commission, the European Court), and non-governmental organizations, which are usually non-local and possibly of international origin.

Due to the great variety of type and scope of protests, conflicts and environmental movements, it is not possible to determine the precise range of actors involved from the literature review alone. The identities of the actors are directly related to the nature of the protest, conflict or movement, to its origins

Sociedade \& Natureza, Uberlândia, 21 (1): 51-70, ABR. 2009 
(nature of impact) and to the geographical area of incidence or potential incidence, as well as its scope (strictly local, municipal or regional, amongst others).

In terms of dealing with impacts or environmental problems, which are primarily found in urban areas, local governance, from both the urban and environmental perspectives, has a role to play and its performance in resolving local protests is indisputably of importance.

It is pertinent to mention that the concept of governance emphasises the changing nature of the concept of "government", through which the involvement of collective actors in addressing or managing a particular issue can be identified (FRIEDMANN, 1998, apud SAVAN, GORE and MORGAN, 2004, p. 607).

Working from the urban governance perspective, Harpham and Boateng (1997, apud Brunckhorst, 1998, p. 71), pointed out the importance of the relationship between the environment and institutions which are accountable for maintaining and improving local public assets and compliance with environmental rules, as previously mentioned.

Savan, Gore et al. (2004) think that governments should be capable of responding with enforcement measures when local citizens raise concerns that relate to the degradation of environmental quality. However, with respect to environmental complaints, the performance of local government is measured not only by their responsibility for resolving protested issues, but also by the warnings issued on the sources of environmental damage and the creation of appropriate conditions for mitigating or eliminating these.

The European Union has played an important role in the proposal of strategies and instruments which promote the prevention and resolution of urban environmental problems. Amongst other documents which propose guidance on this matter, the $5^{\text {th }}$ Environmental Action Programme of the European
Community, the European Sustainable Cities and Towns Campaign and the $6^{\text {th }}$ Environmental Action Programme of the European Community and, resulting from the last of these, the Thematic Strategy on the Urban Environment (2006) are of significance. The implementation of this strategy is considered to be an important contribution to the improvement of urban environmental quality and reduction of the negative environmental impacts caused by cities. Some other relevant guidance at international and European levels, such as Local Agenda 21 (Chap. 28 of Agenda 21) and the Aalborg Charter, are also of relevance since they have strongly influenced local strategies for sustainability throughout the world.

In Portugal, the legal framework for urban environmental quality can be found in a dispersed set of documents which includes the Framework Law for Territorial Planning, and its corresponding regulations. Together these determine the main rules for land use planning, and sector-based environmental legislation, via which air and water quality, noise levels and waste management and control measures are established. Despite a coherent evolution and consolidation, this vast and dispersed legal framework can neither be easily operationalised by local authorities nor assimilated by the public in general, thus it tends to hinder effective local environmental management and the prevention of urban problems.

\section{Case Study Methodology}

This article presents the main results of a study into complaints about environmental problems submitted to the Environmental Department of the Aveiro City Council, Portugal, between 2000 and 2005.

The municipality of Aveiro, with approximately 73,000 inhabitants, is located on the central section of Portugal's Atlantic coast (see FIG. 1). One third of its territory is classified as Natura 2000, under the European Birds Directive (see FIG. $1)$. 


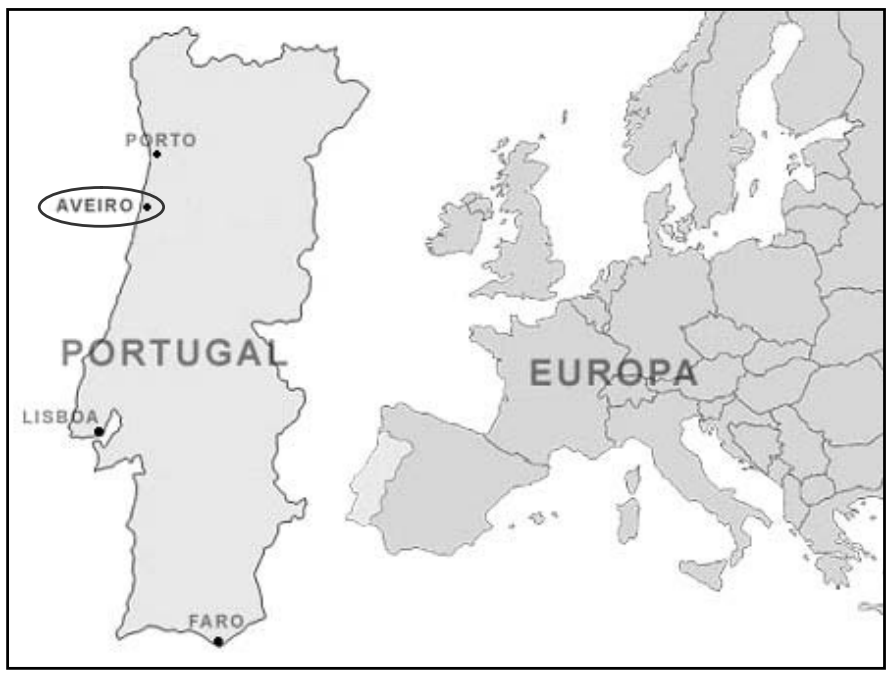

Figure 1. The location of Aveiro, Portugal.

Source: adapted from AMRIA.

The empirical research methodology consisted of the identification and critical analysis of the complaints. On being identified, the cases (the cases are equivalent to the files submitted; although one case can contain more than one complaint) were categorised according to: (i) identification, (ii) administrative proceeding, (iii) location, (iv) type of environmental problem and (v) findings. The table also contains comments where appropriate (see Tab.1). This classification enabled the identification of: the local actors involved, the protest factors, and, consequently, the nuisance factors associated with environmental problems, their location, and the local authority's reaction towards the cause of the protests as well as its interventional path in solving the problems.

Table 1. Framework of case analysis

\begin{tabular}{|l|l|}
\hline & 1.1. Claimant \\
& 1.2. Invoked actors \\
& 1.3. Source of environmental damage \\
\hline & 2.1. No. of the procedure/complaint \\
& 2.2. Date of registration \\
2. Administrative proceeding & 2.3. Date of resolution \\
& 2.4. Progress \\
\hline & 3.1. Location \\
3. Location & 3.2. Parish \\
\hline 4. Environmental problem typology & 3.3. Territorial planning \\
\hline 5. Findings & Nature of the impact \\
& 5.1. Resolution of administrative proceedings \\
& 5.2. Resolution of environmental problems \\
\hline Remarks & \\
\hline
\end{tabular}


Using this framework, the analysis of the complaints included identification of the claimants, the sources of environmental damage and the identity of the actors intended to resolve the environmental problems, identification of the processes, location of complaints, types of environmental problems and resolutions. Thus, it was possible to identify which sectors of society are more involved in the protests, the sorts of environmental problems that are found as well as their territorial distribution, and, additionally, the way in which the administrative proceedings and their associated environmental problems were handled, where these were the responsibility of the City Council.

After that, the data were input into NUD*IST 6, which allowed the data base to be matched and interpreted in terms of the research questions.

The inclusion of the third item, "Location", enabled the identification of the territorial distribution and concentration of the complaints and also their contextualisation in terms of the different land uses and territorial plans for Aveiro, as drawn up in the Municipal Master Plan. The land use types and territorial plans were divided into six groups which were: natural conservation areas, agricultural forested zones, built-up zones, water courses and wetlands, and areas with special plans or land uses.

The environmental problems found in the complaints were classified into the following type groups - abandoned residences/lots, abandoned vehicles/objects, air, damage to the vegetation, disease vectors/insects, fauna damage, noise, solid waste, unsanctioned activities and businesses water and sewerage, and "others".

The procedural handling of the cases dealt with between the end of 2006 and beginning of 2007 was followed through the Aveiro City Council's IT system. This made it possible to identify the way in which the complaints were resolved and the time lapse between their initial registration and case closure.

It is relevant to emphasize that the resolution of a complaint does not necessarily mean that associated environmental problem has been solved, since such resolution may involve palliative measures capable of mitigating, but not eliminating, the effects of environmental damage.

Consultation of the case procedures in the computer systems mentioned above did not yield information on the way in which the environmental problems had been resolved. Therefore, and in order to obtain this information, members of the Environmental Department of the City Council were consulted directly.

Complaint locations were geo-referenced on the CMA's 1:10,000 scale cartographic base using AutoCAD 2007. Locations were fixed in accordance with the places given in the case files, except for those ten cases in which the complaint location was not identified.

Two goals were defined in drawing up the thematic maps:

i) A global analysis of the territorial distribution of complaints located by points on the map;

ii) A per capita analysis of the distribution of complaints based on the measure "[(number of complaints/resident population) x 100]".

\section{Results}

The data was processed so as to be able to show the temporal evolution of the number of complaints, the sorts of claimants, the sources of environmental problems and the actors co-opted to deal with them, the types of those environmental problems which significantly disturb the members of the public (and which have led them to present a formal protest), their territorial distribution in the municipality, the type of land use associated with complaint location, the process of the administrative handling and resolution of the associated environmental problems as well as the time lapse between initial complaint registration and case closure. 


\subsection{Annual development of complaints}

The study found that a total of 370 complaints were presented between 2000 and 2005. The development over time of complaints filing reveals a significant annual increase, with a slight decrease in 2005, and a good linear correlation in terms of the number of complaints (see Graf. 1).

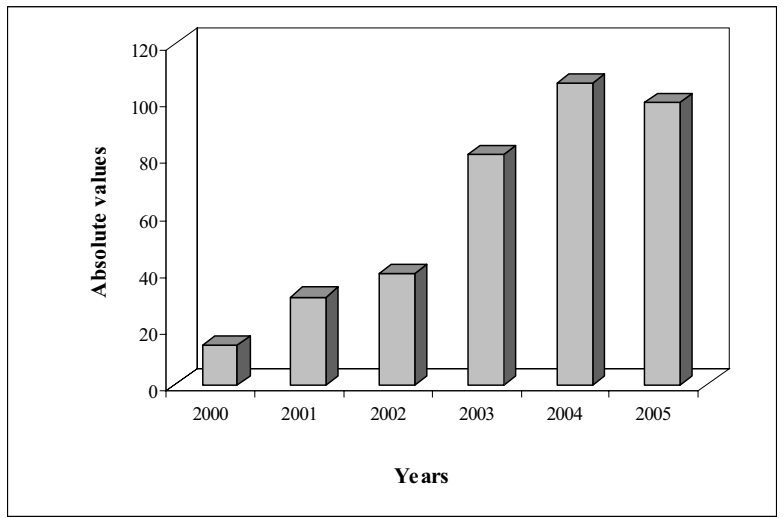

Grafic 1- Development of the number of complaints.

\subsection{Complainants, sources of environmental damage and invoked actors}

Analysis of the complainants revealed seven types: citizens, local institutions, regional institutions, services, industries, associations and others in the case of complainants with uncertain or unknown identities (see Graf. 2).

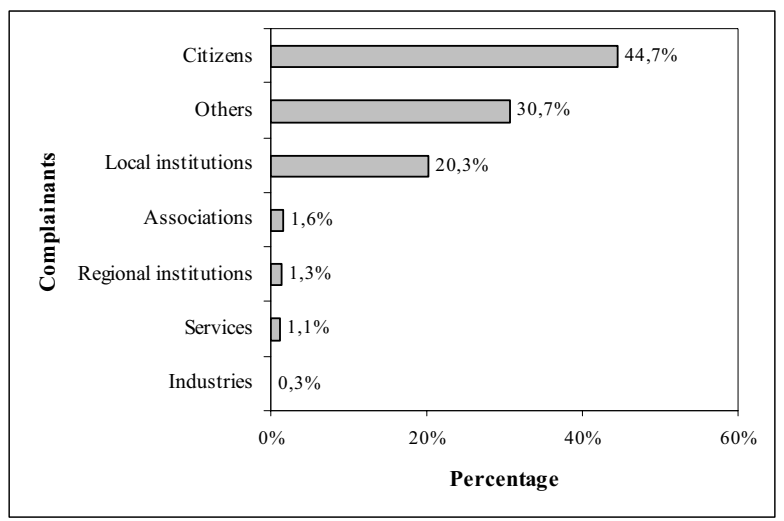

Grafic 2. Types of complainants.

Citizens and local institutions are the two sectors of society which submitted the most protests to the City Council, followed by associations, regional institutions services and industries. In classifying complainants, those that were unidentified were categorised as 'others', and this proved to be the second largest group. In this category, locally printed news motivated the submission of 8 complaints. However, it was not possible, from the documents consulted, to identify those responsible for making the complaints to the City Council. However, it was clear that the news had led to their submission.

Interpretation of these documents also revealed those who were either responsible for the environmental damage or who were potential factors of impact. These were identified as "sources of environmental problems" and included, in decreasing order, others, for those who were unidentified or unknown sources of environmental problems; citizens; services, meaning commercial establishments and service providers; inaction on the part of bodies with responsibility for the environment; local institutions; industries and finally farming and cattle raising activities (see Graf. 3 ).

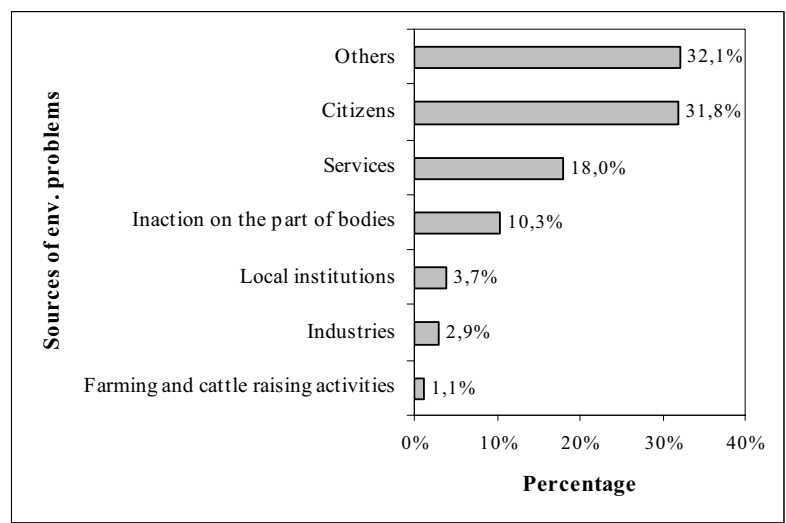

Grafic 3. Sources of environmental problems.

The complaints invoked five types of actors for resolving the problems: citizens, local institutions, regional institutions, services and industries (see Graf. 4).

This analysis clearly shows the preponderance of local institutions, with $67.7 \%$ of the total, followed by services, citizens and regional institutions, and finally industries in the resolution of the environmental problems found in the complaints. 


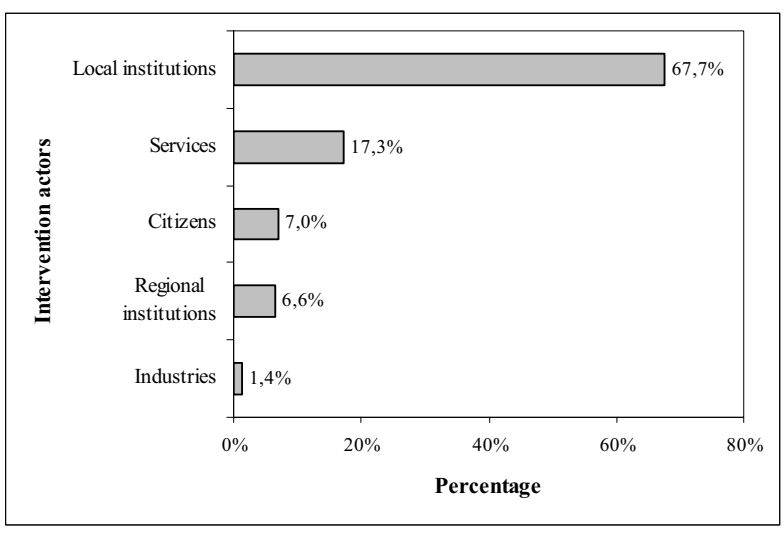

Grafic 4. Intervention actors.

\subsection{Types of environmental problems referred to in the complaints}

The analysis of the complaints by type of environmental problem reveals that the ones which were more bothersome were solid waste, water and sewerage, followed by vehicles and objects abandoned in public areas and noise (see Graf. 5).

The next most numerous categories are those of disease vectors and insects and abandoned residences and lots which occurred in a significant

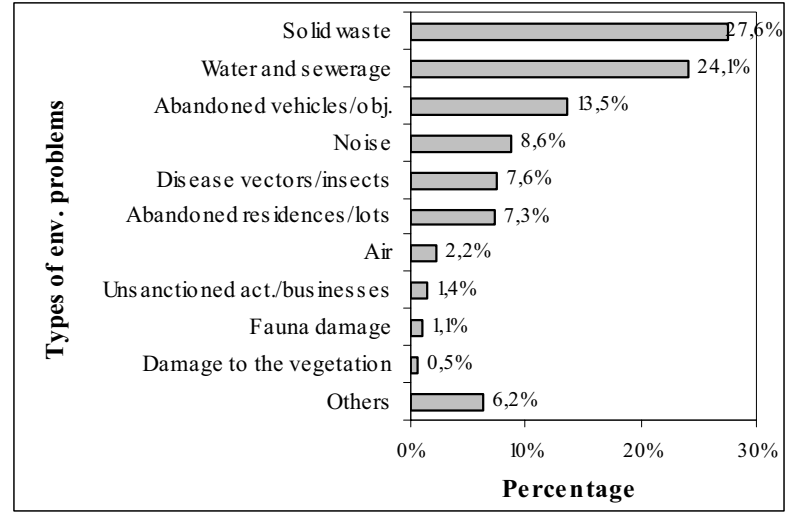

Grafic 5. Types of environmental problems referred to in the complaints.

percentage of protests. Of the same order are the protests classified as others, which occurred in similar proportions to the previous categories. The environmental problems which led to a low number of complaints were, in decreasing order, air, unsanctioned activities and businesses, fauna damage and damage to vegetation.

A further analysis of the types of environmental problem by subcategory reveals more complete details about the types and frequencies of occurrence by type of these protests (see Tab. 2).

Table 2. Subcategories of the environmental problem types.

\begin{tabular}{l|l}
\hline Abandoned residences/lots & Abandoned residences, abandoned lots. \\
\hline Abandoned vehicles/objects & Vehicles, cranes, boats, tools. \\
\hline Air & Smells, smoke/soot, fires. \\
\hline Damage to the vegetation & Trees and garden damage. \\
\hline Disease vectors/insects & Fleas, mice, mice and fleas*, ticks, cockroaches, ants, woodworms. \\
\hline Fauna damage & Killing of fish, ducks or swans. \\
\hline Noise & Services, industry, religious institutions, dog barking, non-specified source. \\
\hline Solid waste & $\begin{array}{l}\text { Illegal open air dumps, inappropriate dumping methods, damage to containers, trash } \\
\text { collection, lack of containers. }\end{array}$ \\
\hline Unsanctioned & Unsanctioned activities, irregular business activities. \\
\hline Wativities/businesses & $\begin{array}{l}\text { Pollution/contamination (pollution or contamination of water courses or fountains), erosive } \\
\text { processes, water drainage (floods, runoff, obstruction of water courses, others (non- } \\
\text { specified complaints about water, usually reported on "SOS Ambiente 24"**), drain, } \\
\text { sewage system (rupture, malfunction or obstruction of drainpipes, rupture in the water } \\
\text { supply, problems with the monitoring of water quality, problems with the collecting, } \\
\text { treatment or drainage of wastewater/rainwater, inactivatemechanical ventilators). }\end{array}$
\end{tabular}

\footnotetext{
* In some cases, there were simultaneous complaints about mice and fleas. These counted as just one complaint. It was necessary to create the joint mice and fleas category so that the total number of complaints remained unaltered. ** "SOS Ambiente 24" is a telephone line for the submission of public environmental complaints.
} 
Environmental complaints in Aveiro, Portugal: actors, concerns, territorial pattern, and resolutions Daniela Salgado Carvalho, Teresa Fidélis

The percentage distribution of the shown in Tab. 3. subcategories of types of environmental problem is

Table 3. Percentage distribution of the subcategories of environmental problem types.

\begin{tabular}{|c|c|c|c|c|c|c|c|c|c|}
\hline \multicolumn{2}{|c|}{ Solid waste } & \multicolumn{2}{|c|}{$\begin{array}{l}\text { Water and } \\
\text { sewerage }\end{array}$} & \multicolumn{2}{|c|}{$\begin{array}{c}\text { Abandoned } \\
\text { vehicles/objects }\end{array}$} & \multicolumn{2}{|l|}{ Noise } & \multicolumn{2}{|c|}{$\begin{array}{l}\text { Disease vectors/ } \\
\text { Insects }\end{array}$} \\
\hline $\begin{array}{l}\text { Illegal open } \\
\text { air dumps }\end{array}$ & 37.3 & Sewage & 34.8 & Vehicles & 94.0 & Services & 71.9 & Mice & 50.0 \\
\hline $\begin{array}{l}\text { Damage to } \\
\text { containers }\end{array}$ & 30.4 & $\begin{array}{l}\text { Sewerage } \\
\text { infrastructure }\end{array}$ & 28.1 & Boats & 2.0 & Industries & 9.4 & $\begin{array}{l}\text { Mice and } \\
\text { fleas }\end{array}$ & 17.9 \\
\hline $\begin{array}{l}\text { Trash } \\
\text { collection }\end{array}$ & 16.7 & $\begin{array}{l}\text { Pollution/ } \\
\text { contamination }\end{array}$ & 19.1 & Cranes & 2.0 & $\begin{array}{l}\text { Religious } \\
\text { institutions }\end{array}$ & 9.4 & Fleas & 17.9 \\
\hline $\begin{array}{l}\text { Inappropriat } \\
\text { dumping } \\
\text { methods }\end{array}$ & 13.7 & $\begin{array}{l}\text { Water } \\
\text { drainage }\end{array}$ & 10.1 & Tools & 2.0 & $\begin{array}{l}\text { Non- } \\
\text { specified } \\
\text { sources }\end{array}$ & 6.3 & Ticks & 3.6 \\
\hline \multirow[t]{3}{*}{$\begin{array}{l}\text { Lack of } \\
\text { containers }\end{array}$} & 2.0 & Others & 4.5 & & & $\begin{array}{l}\text { Dog } \\
\text { barking }\end{array}$ & 3.1 & Cockroaches & 3.6 \\
\hline & & $\begin{array}{l}\text { Erosive } \\
\text { processes }\end{array}$ & 3.4 & & & & & Ants & 3.6 \\
\hline & & & & & & & & Woodworms & 3.6 \\
\hline \multicolumn{2}{|c|}{$\begin{array}{c}\text { Abandoned } \\
\text { residences/lots }\end{array}$} & \multicolumn{2}{|c|}{$\begin{array}{c}\text { Unsanctioned } \\
\text { activities/ } \\
\text { explorations }\end{array}$} & \multicolumn{2}{|c|}{ Air } & \multicolumn{2}{|c|}{ Fauna damage } & \multicolumn{2}{|c|}{$\begin{array}{l}\text { Damage to the } \\
\text { vegetation }\end{array}$} \\
\hline $\begin{array}{l}\text { Abandoned } \\
\text { lots }\end{array}$ & 74.1 & \multicolumn{2}{|c|}{$\begin{array}{c}\text { Unsanctioned } \\
\text { activities }\end{array}$} & Smells & 75.0 & Killing fish & 75.0 & $\begin{array}{l}\text { Tree } \\
\text { damage }\end{array}$ & 50.0 \\
\hline \multirow[t]{6}{*}{$\begin{array}{l}\text { Abandoned } \\
\text { residences }\end{array}$} & 25.9 & Scrap yard & 33.3 & Fires & 12.5 & $\begin{array}{l}\text { Killing } \\
\text { ducks/swans }\end{array}$ & 25.0 & $\begin{array}{l}\text { Garden } \\
\text { damage }\end{array}$ & 50.0 \\
\hline & & $\begin{array}{l}\text { Unhealthy } \\
\text { slaughterhouse }\end{array}$ & 33.3 & $\begin{array}{l}\text { Smoke/ } \\
\text { soot }\end{array}$ & 12.5 & & & & \\
\hline & & Parking lot & 33.3 & & & & & & \\
\hline & & \multicolumn{2}{|c|}{$\begin{array}{l}\text { Irregular business } \\
\text { activities }\end{array}$} & & & & & & \\
\hline & & $\begin{array}{l}\text { Unlicensed } \\
\text { sand-clay pit }\end{array}$ & 50.0 & & & & & & \\
\hline & & Cattle breeder & 50.0 & & & & & & \\
\hline
\end{tabular}

In the case of solid waste, the type analysis revealed that illegal open air dumps were most annoying followed by damage to containers. In third place were problems related to trash collection, then inappropriate dumping methods, and finally lack of containers.
Sewage was the most frequently protested type in the water and sewerage category. This included the dumping of untreated sewage into watercourses or into public thoroughfares. Next most common in this category were complaints relating to sewerage infrastructure, pollution or contamination of watercourses or reservoirs, followed by others, a 
catch-all category for isolated episodes of protest, and then, finally, erosive processes.

Abandoned vehicles, all classified as light vehicles, were by far the most common source of complaints in the abandoned vehicles and objects category, accounting for over $90.0 \%$ of the total. In addition to such vehicles, complaints were also registered which related to the abandonment of boats, cranes and tools on public thoroughfares.

Services were the most frequently responsible sources of noise, at over $70.0 \%$. Less frequently, complaints were made, in decreasing order, about industries and religious institutions, non-specified sources and dog barking.

As regards the appearance or proliferation of disease vectors and insects, merging the subcategories mice, mice and fleas and fleas, accounts for more than $85.0 \%$ of the complaints, which indicates the commonness of these rodents and parasites. The other subcategories, namely ants, cockroaches, ticks and woodworms, were less reported.

The data showed that abandoned lots, which always co-occurred with other factors in complaints, had led to most of the protests in the abandoned lots and residences categories. These protests were also associated with other types of impact, more specifically solid waste and disease vectors and insects.

Three subcategories were identified in airrelated protests, namely smells, fires and smoke and soot. Most complaints were about smell, followed by fires and smoke and soot which had the same frequencies.

Despite the low frequency of complaints, the protests concerning unsanctioned activities and businesses related to very different situations. The protests about unsanctioned activities detailed the existence of an unsanctioned scrap yard, an unhealthy slaughterhouse and an unlicensed parking lot, which was also associated with another type of environmental problem, noise. The protests regarding irregular businesses showed the existence of an unlicensed sand-clay pit, and a cattle breeder where the run off led to the pollution of a water course. The protests about fauna damage concerned situations related exclusively to the death of fish, ducks and swans as the result of water pollution. Finally were the complaints concerning damage to vegetation, associated with tree damage and garden damage.

\subsection{Territorial Analysis of Complaints}

\section{Territorial Distribution}

The territorial distribution of complaints is shown in Fig. 2. This analysis reveals that there is a greater concentration of complaints in the parishes closer to the urban centre and that these constitute a kind of blemish around the central part of the city. The highest number of complaints within these parishes relate to water and sewerage and solid waste management, which is rather curious given that the environmental infrastructure is more developed in these areas. In the peripheral parishes the environmental problems tend to be less diversified in type and generate a lower intensity of complaints. 


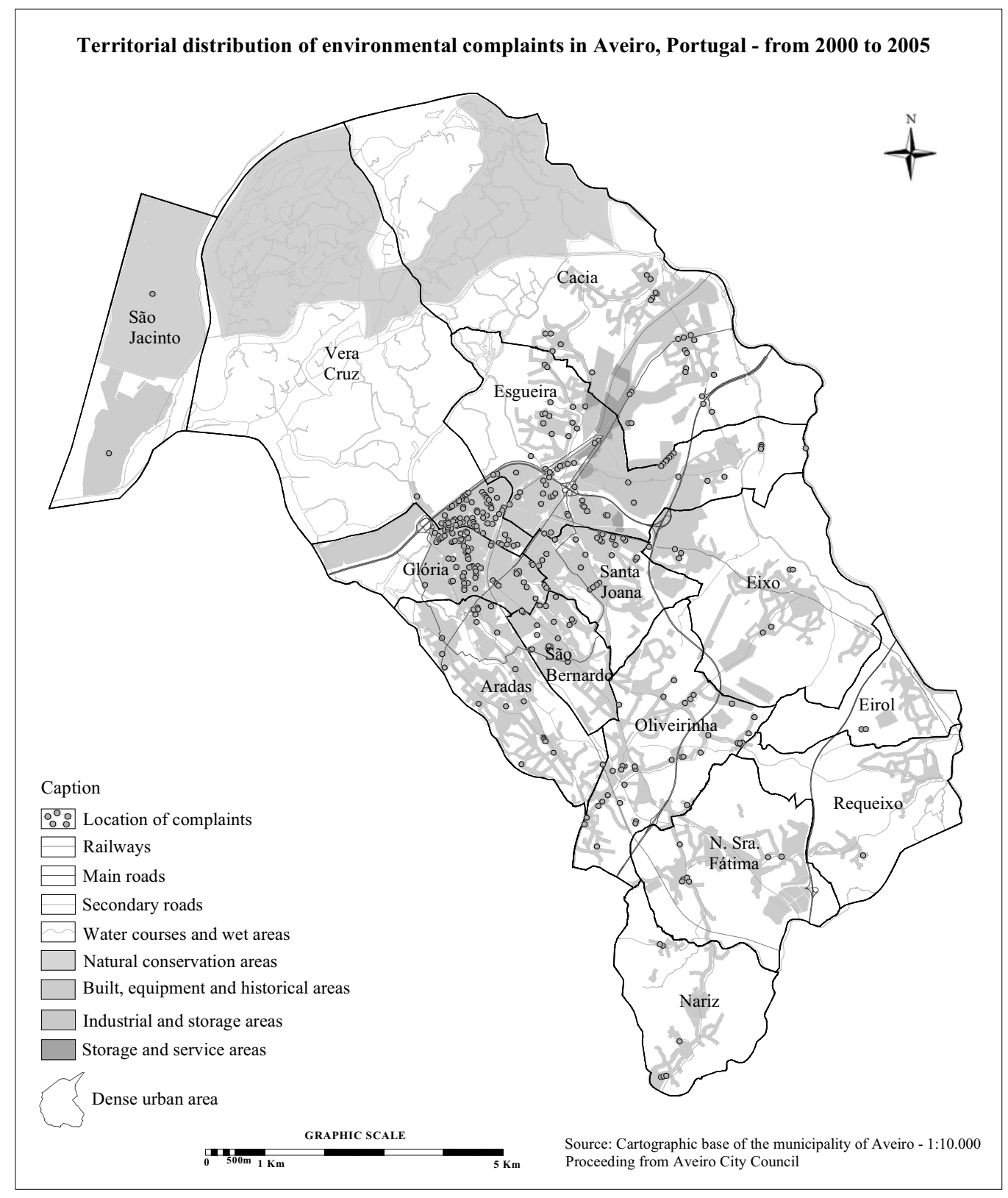

Figure 2. Territorial distribution of complaints.

\section{Territorial Concentration}

Bearing in mind the demographic data relating to the municipality of Aveiro (INE, 2001), the territorial concentration of the complaints shows that there is a close relation between the number of complaints and the size of the resident population within the parishes. This behaviour is predictable since the effects of urban pressure on the environment tend to be more concentrated where there is a higher urban population density.

Fig. 3 shows the per capita distribution of complaints based on the measure "[(number of complaints/resident population) x 100]".

The data showed high levels of complaints in the parishes closest to the urban centre: Glória, Vera

Sociedade \& Natureza, Uberlândia, 21 (1): 51-70, ABR. 2009 
Cruz and Esgueira, which contain about $42.0 \%$ of the municipality's total population. Despite the absence of noise complaints, the parish of Oliveirinha, together with Esgueira, Glória and Vera Cruz are the parishes with the greatest diversity and the highest number of complaints. These four parishes are responsible for 243 of the 370 complaints, or $65.6 \%$ of the total. In the peripheral parishes the intensity of complaints per capita tends to be lower.
The parishes of São Bernardo, Santa Joana and Glória have the highest demographic densities of the municipality. It is relevant to mention the population growth occurring in the parishes of São Bernardo and Vera Cruz as this emphasizes the relation between 'population and frequency of complaints', since these parishes show high levels of per capita complaints.

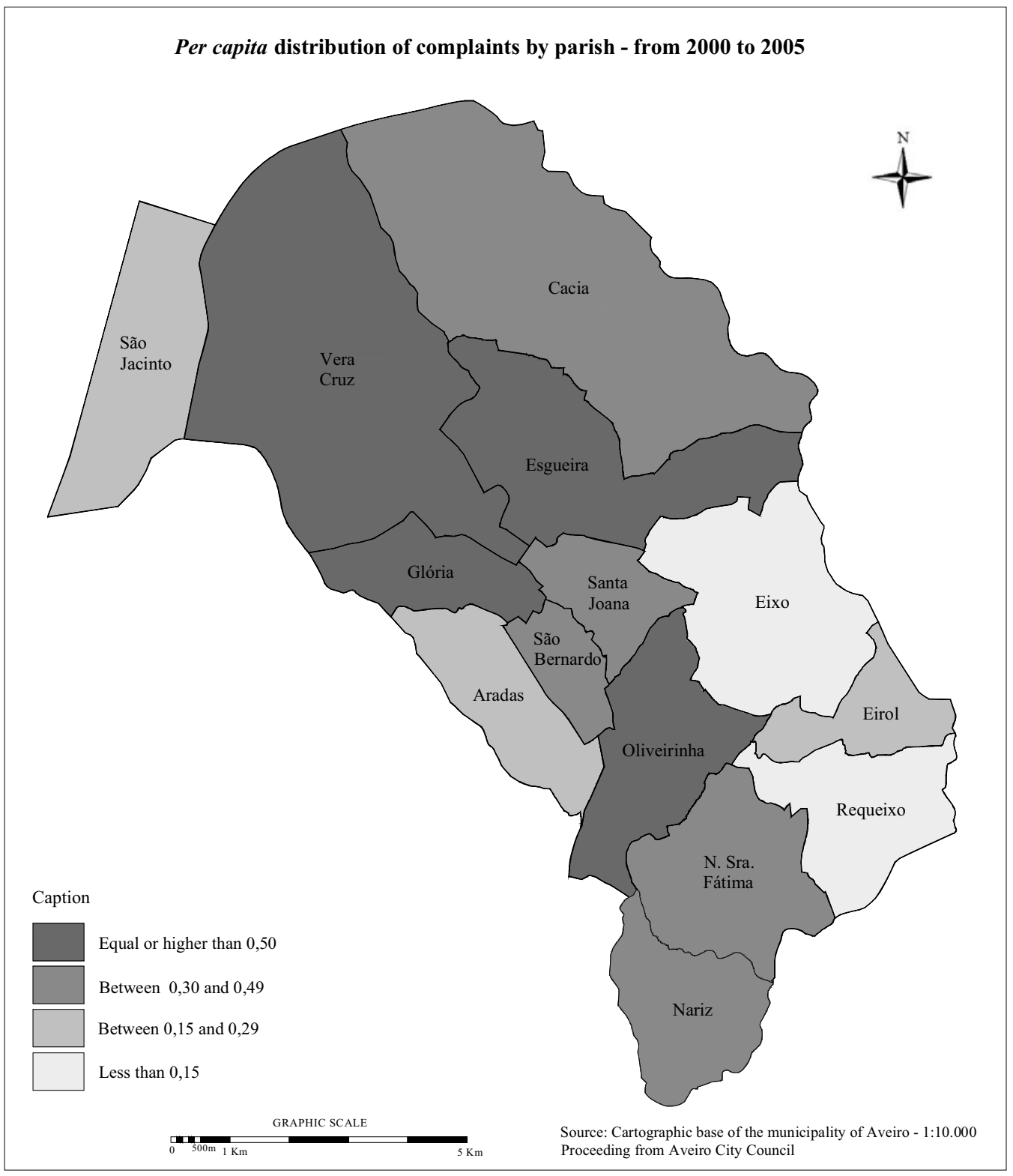

Figure 3. Territorial concentration of complaints. 


\subsection{Land Use Analysis}

The analysis of the location referred to in the complaints in relation to the land use scheme was based on the Municipal Master Plan. Using the land use categories in this plan, five analysis groups were defined:

- Nature: natural conservation area, Natura 2000 network, S. Jacinto Dunes Nature Reserve, coastal sands, national ecological reserve.

- Water: fluvial domain and maritime domain.

- Agricultural forest: agricultural and forest zones and national agricultural reserve.

- Building: Built Zones I, II and III, industrial and storage zones, services and storage zones, and equipment zones.

- Special zones: zone with special plan, airfield protection zone, Protection and Nonedificandi Built Zones, detailed plans.

Based on the structure mentioned above, the distribution of the groups of analysis is as shown below (Graf. 6):

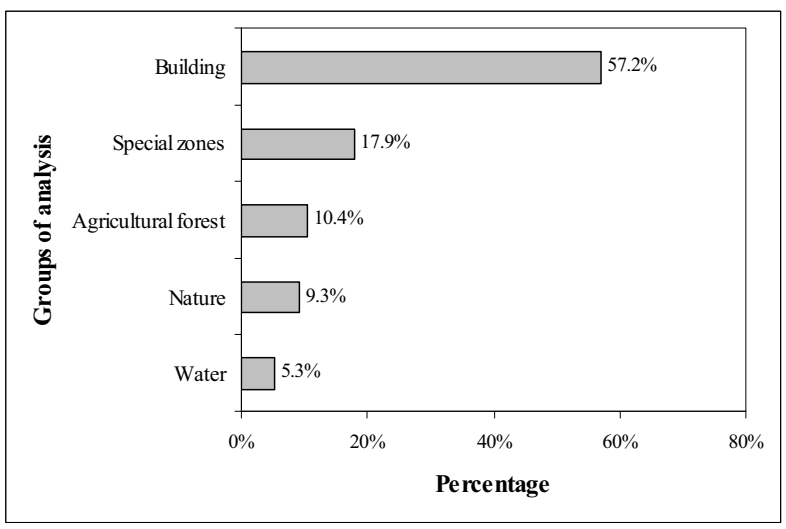

Grafic 6. Percentage distribution of the land use analysis groups.

The data show a concentration of complaints in the built-up areas and areas of public use, as found in the both the "building" and "special zones" groups, which together form the densest urban areas in the municipality. Together, these groups accounted for $75.1 \%$ of the total number of complaints, which may indicate a higher sensitivity on the part of the complainants in relation to the environmental problems which directly affect the quality of life of the local population. By comparison, the groups "nature", "water" and "agricultural forest", which together form the natural areas in the municipality, accounted for just $25.0 \%$ of the total of complaints. Here environmental protection may be the most important motivation for the submission of protests, as they would be more relevant than any environmental values which directly affect the quality of life of the local population.

\subsection{Resolution of Complaints and Solving Environmental Problems}

The resolution of complaints involves the City Council looking for solutions or even forwarding the processes to external entities that are responsible for responding to the administrative proceedings. Thus, the resolved complaints were classified as closed. In course complaints have their ongoing processes registered in the City Council's document management system and the details of unregistered or unidentified complaints could not be consulted (see Graf. 7).

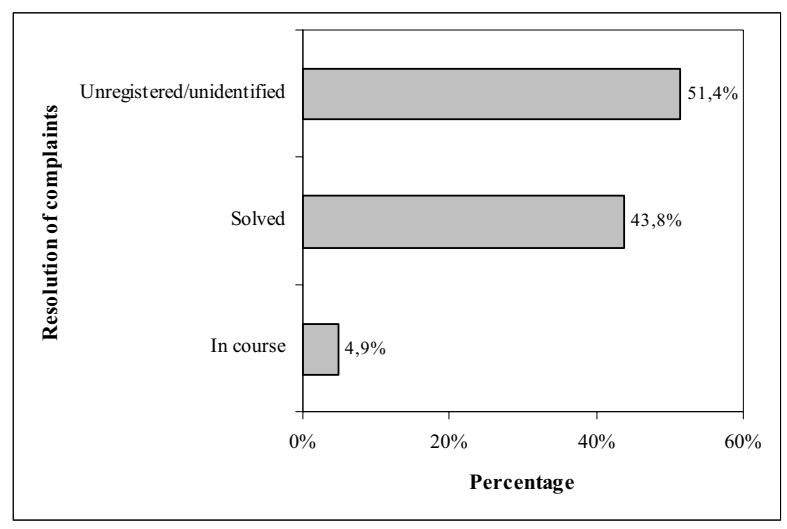

Grafic 7. Resolution of complaints.

Generally speaking, it is unknown if such complaints were resolved, and they represent more than $50.0 \%$ of the total. The next categories are closed and in course administrative proceedings.

The disadvantage of the unregistered or unidentified categories is that they could be either 
closed or in course. Nevertheless, the data showed a preponderance of closed processes.

In consulting the solving of environmental problems, four categories were identified: solved, in course, unsolved and unknown. This last of these corresponds to the category unregistered or unidentified in the resolution of complaints. Graf. 8 shows the percentage distribution of these data:

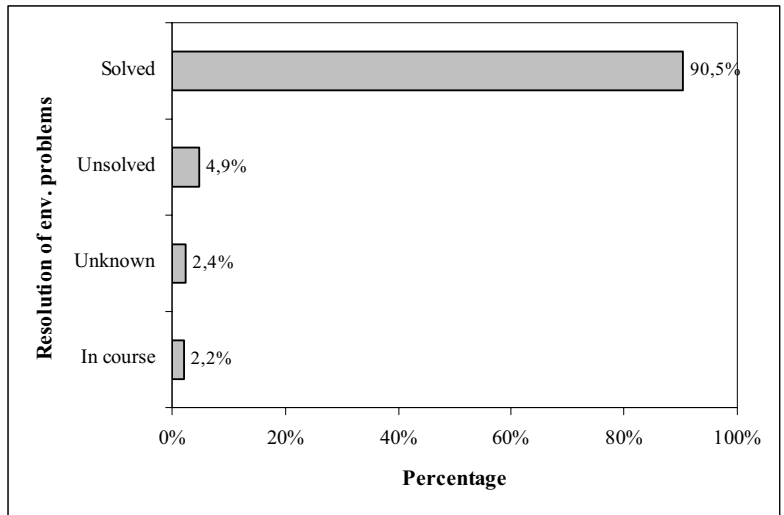

Grafic 8-Resolution of environmental problems.

The data showed that $90.5 \%$ of environmental problems were solved, which indicates a strong commitment to solving the problems found in the complaints. The unsolved environmental problems represented less than $5.0 \%$ of the total, and this was followed by the unknown and in course resolutions, with the lowest values observed.

\subsection{Closing complaints}

This section looks at the time lapse from complaint registration to closure when both registration and closure dates are known. However, the time between the registration of complaints and the resolution of the environmental problems was not included, as this data were not analysed in a digital environment, and this kind of data was not registered in the City Council's document management system.

The intervals used in this analysis were: $u p$ to 6 months, from 6 months to 1 year, from 1 to 2 years, from 2 to 3 years, from 3 to 4 years, more than 4 years and unknown / in course - this last one for the complaints which were not closed or whose timeline is not known.

This information, together with information on the complaints, was obtained from the records, held in the City Council's document management systems, that referred to the period 2000 to 2006 (some intervals are not applicable throughout. Therefore, for the years 2004 and 2005 the intervals from 3 to 4 years and more than 4 years are not applicable; for the years 2003 and 2002, the interval more than 4 years is not applicable and, for the years 2000 and 2001 all the intervals are pertinent). The following percentage distribution was found (Graf. 9):

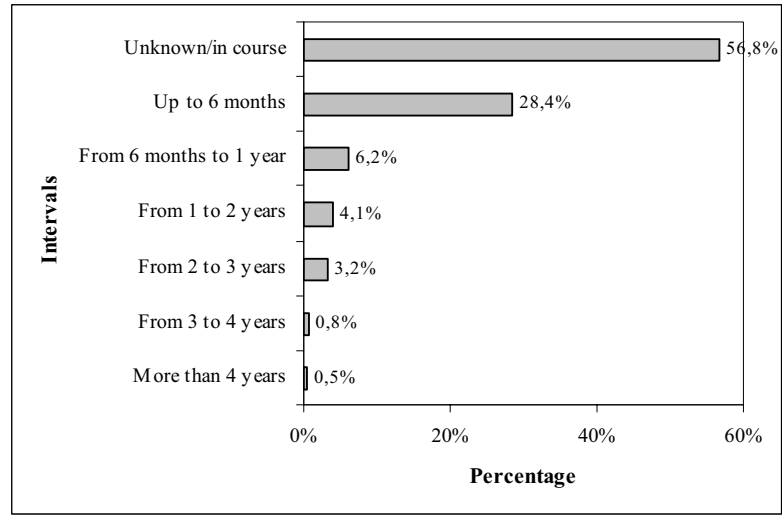

Grafic 9 - Time spent from the registration to closure the complaints.

The category unknown / in course predominated over the others, showing that most of the complaints had not been registered when they were solved, or that the processes are still in course. The most common time lapse was the up to 6 months interval, which indicates that a significant number of registered process complaints were resolved after a short time (only 160 of a total of 370 complaints, or $43.2 \%$, have a registration and closure date). The next most common interval was from 6 months to 1 year, followed by the intervals from 1 to 2 years and from 2 to 3 years. The intervals from 3 to 4 years and more than 4 years were least frequently observed.

\subsection{Results discussion}

Firstly, the results focus on the types of 
environmental problems which hold a higher nuisance value for the population. Solid waste, water and sewerage, abandoned vehicles and objects and noise were the issues most commonly mentioned in the complaints.

The predominance of these types of environmental problems, with the exception of abandoned vehicles and objects, in this study shows the same tendency as observed in the costs or impacts resulting from the urbanisation processes and as reported in the expert literature. The United Nations Environment Programme (2002) mentions that, in the case of European urban areas the crucial matters are urban air quality, noise and solid waste.

It also highlights urban solid waste management as one of the main concerns of modern societies (see for example BINDÉ,1998; UNEP, 2002). This smaller scale study of environmental complaints generally concurs, in its identification of the most significant environmental problems within the study area, with the findings of such larger scale analyses.

Interestingly, the abandonment of vehicles and objects led to a comparatively large number of complaints when compared with some "classic" urban environmental problems, such as massive air pollution (see for example, BINDÉ, 1998; SUKOPP and WERNER, 1972 apud NUCCI, 2001), which were of less nuisance to the local population. The abandonment of vehicles or objects is obviously a problem of considerable importance to the local population, who appear to object to the visual impact and the improper occupation of public spaces.

The National Institute of Statistics holds data on the environmental complaints made throughout Portugal which is differentiated by types of pollution, more specifically noise, air, water and others. Even though outdated, this data gives an overview of the development of environmental complaints in Portugal between 1990 and 1998 and the sorts of pollution most complained about between 1991 and 1999. When compared with the results of this empirical study, the complaints about water on a national scale are, broadly speaking, of a similar nature to those found in the study although the relative proportions differ. On the other hand, complaints about air pollution, one of the most complained about types of pollution on the national scale, are far less common in this study.

Another interesting aspect relates to the location of complaints about noise, which are concentrated in the urban centre. Table 3, which, amongst others, maps the distribution of noise sources, shows that the complainants are more sensitive to noise originating from commercial activities, rather than the traffic noise which is a common environmental problem in urban areas, especially in urban centres and areas of intense traffic, as has been pointed out by UNEP (2002, p. 275) which defines this as an urgent matter to be dealt with in European urban areas.

Studies on the perception of environmental quality, such assuch as Jacobi (1994), Izazola, Martínez et al. (1998), Bonaiuto, Aiello et al. (1999), Bonaiuto, Fornara et al. (2003), Marans (2003), Bonaiuto, Fornara et al. (2006), Esengun, Sayili et al. (2006) amongst others, have mostly been carried out in urban areas and have described a number of indicators and forms for the evaluation of environmental quality. These focus on the environmental problems that significantly concern the interviewed population and authorities. Air pollution, noise, solid waste, water pollution, lack of green areas, drains and soil pollution, with evidence to suggest that air pollution and noise are the most commonly mentioned issues, are examples of the environmental problems found in these studies. There are, thus, considerable similarities with the results presented here.

The results also emphasised the location of complaints, which were mostly concentrated in dense urban areas. This behaviour can be linked, to a certain extent, to the assumptions made by Bindé (1998), Newman (2006) and Brentwood (2006), who identified that people usually have a negative effect on the environment. 
The actors involved in the protests or environmental conflicts described by Kousis (2001) are generally the same actors as are involved in the complaints analysed here. Citizens figure as important local actors of mobilization and protest and the local authorities as the agents responsible for solving environmental problems or conflicts.

Another aspect to be highlighted is the importance of local governance to the environment(see for example HARPHAM AND BOATENG, 1997; SAVAN, GORE et al., 2004). The study of complaints can serve as a useful indicator of local governance performance. The results of the empirical study give a general overview of the resolution of complaints and the solving of environmental problems as well as the time spent from registration to closure, where applicable, of the administrative proceedings. The responses given by the City Council, in its attempt to solve or to forward the administrative proceedings, were identified. These showed a significant number of solved or relieved environmental problems; however, the nature of the responses and their level of (in)effectiveness could not be determined.

Finally, and as indicators of the perception of environmental quality, the study of the complaints brought to the fore those matters which significantly disturb the local population. These proved to concur with the wider concept of environmental quality described in the expert literature (PACIONE, 2003; VAN KAMP, LEIDELMEIJER et al., 2003), in which subjective indicators (the public's environmental perception in this specific case) are of great relevance.

\section{Conclusions}

The complaints on environmental matters which are submitted to the City Council, which has an important role to play in the management of environmental quality, have the potential to reveal to researchers the perception of environmental quality in urban and periurban areas as well as the perception of environmental problems as seen by local actors. This is possible due to the fact that the complaints reveal the population's concerns, protests and demands in this domain and, more specifically, at the local level. This knowledge is relevant to a selfevaluation by the local authority whilst remaining a promising avenue for public participation in decision making processes at the local level.

This study identified three main types of local actors: complainants, those required to intervene in resolution processes and those seen as sources of environmental damage. In concrete terms these were citizens, local institutions and citizens again. The predominance of citizens as complainants and as sources of environmental damage reveals that the local actors who complain more frequently belong to the same class as those who caused the environmental problems found in most of the complaints analysed here. The results also revealed the main concerns intrinsic to these protests in that solid waste, water and sewerage, abandoned vehicles and objects, noise, disease vectors and insects and abandoned residences and lots were deemed to be the main sources of nuisance. Other sorts of environmental problems were identified as being less frequent, particularly unsanctioned activities and businesses, air quality, damage to the vegetation and fauna damage. There were a significant number of complaints categorised as others and referring to situations in which there was no actual environmental damage. These showed that there is a wide range of sources of nuisance to the general public.

The territorial analysis enabled the two main parts of this study to be brought together: qualitative and territorial. The inclusion of the land use pattern in this analysis allowed for the identification of "preferential zones" of incidence of environmental problems which had motivated the submission of complaints, namely the dense urban areas, and specifically the building and special zones subcategories.

The final part of this complaints' study involved analyzing the resolution of complaints, the solving of the environmental problems and also the time lapse between complaint registration and closure. 
This showed that the City Council has been extremely willing to respond to the complaints and their associated environmental problems.

In the overall picture provided by this study, it is possible to discern some failures in the way data is registered and treated by the City Council. As an indicator of perception of environmental quality, the knowledge and management of this information can positively influence the decision-making processes, enabling a more directed and efficient execution of local governance.

Despite the relevance of this empiric study in identifying the main environmental concerns within the municipality, it is possible to conclude that some environmental matters cannot be identified on the basis of the study of environmental complaints alone.

First of all, the complaints are indicators of environmental perception and, when assuming this character, they should be capable of identifying the most critical and the most favourable areas within the municipality. Even though they are an important indicator, the environmental complaints do not have the potential to act as an accurate evaluation of local environmental problems per se, which means that to work with a good level of detail it is necessary to combine this information with other complementary indicators.

In Aveiro, it proved possible to successfully merge the information from environmental and territorial studies of the municipality. This resulted in the definition of diagnoses and plans for the environment, sustainable development and territorial planning, and the complaints on environmental problems submitted to the City Council, so as to give a reliable and more in-depth analysis which has been enriched by the perception of local actors.

The complaints analysis revealed the predominance of protests relating to problems of an immediate nature, particularly those which are most visible, which directly affect the quality of life and well-being of the local population. This means that the local actors protest more about what they see and feel, as confirmed by the low frequency of protests relating to air quality.

Proper management of this information, operating as an indicator of the perception of environmental quality which is based on an understanding of the dissatisfaction of population in relation to the environment, can positively influence the decision-making processes, allowing a more directed and efficient performance on the part of local government.

\section{Acknowledgments}

The authors are grateful to the AlBan Programme, fellowship n. ${ }^{\circ}$ E05M053040BR, and to the Aveiro City Council.

\section{References}

BINDÉ, J. Cities and environment in the twenty-first century: A future-oriented synthesis after Habitat II. Futures, v.30, n.6, p.499-518, 1998.

BONAIUTO, M., AIELlO, A. $E T A L$. Multidimensional perception of residential environment quality and neighbourhood attachment in the urban environment. Journal of Environmental Psychology, v.19, n.4, p.331-352, 1999.

BONAIUTO, M., FORNARA, F. ET AL. Indexes of perceived residential environment quality and neighbourhood attachment in urban environments: a confirmation study on the city of Rome. Landscape and Urban Planning, v.65, p.41-52, 2003.

Perceived residential environment quality in middle- and low-extension italian cities. Revue Européenne de Psychologie Appliquée/European Review of Applied Psychology, v.56, n.1, p.23-34, 2006.

BRENTWOOD, M. City and Environment. Book review. In BOONE, C.G. and MODARRES, A. (Ed.), Temple University Press, Philadelphia, PA (2006) 221

Sociedade \& Natureza, Uberlândia, 21 (1): 51-70, ABR. 2009 
pages. The Social Science Journal, v.44, n.1, p.197199, 2007.

BRUNCKHORST, D. J. Comment on "Urban Governance in Relation to the Operation of Urban Services in Developing Countries" by Trudy Harpham and Kwasi A. Boateng (Author reply follows). Habitat International, v.22, n.1, p.69, 1998.

CANTRELL, R. D. A method for investigation of environmental complaints. Journal of Environmental Health, v.43, n.1, p.14 -18, 1980.

CARVALHO, D. S. and T. FIDÉLIS. Perception of Environmental Quality in Aveiro, Portugal: an environmental map based on public claims. In: 2ND INTERNATIONAL CONGRESS ON ENVIRONMENTAL PLANNING AND MANAGEMENT, 2007, Berlin. Proceedings of 2nd International Congress on Environmental Planning and Management. Berlin: Technische Universitat Berlin, 2007. p.83 - 86.

DASGUPTA, S. and WHEELER, D. Citizen complaints as environmental indicators: evidence from China. World Bank Policy Research Working Paper Series, Washington, DC, p. 1 - 26, 1997.

ELLIOTT, S. J. A comparative analysis of public concern over solid waste incinerators. Waste Management \& Research, v.16, p.351-364, 1998.

ESENGUN, K., SAYILI, M. ET AL. Perceptions of Environmental Issues in a Turkish Province. Polish Journal of Environmental Studies, v.15, n.4, p.635 642, 2006.

FIGUEIREDO, E. and FIDÉLIS, T. Movimentos ambientais de raiz popular em Portugal (1974-1994). Revista Crítica de Ciências Sociais, v.65, p.151 - 173, 2003.

FIGUEIREDO, E., FIDÉLIS, T. ET AL. Grassroots Environmental Action in Portugal (1974 - 1994). In: Environmental Politics in Southern Europe, M. K. Klaus Eder (Ed.), Kluwer Academic Publishers, 2001. Cap. 8, p.197- 221 .
HARPHAM, T. AND BOATENG, K. A. Urban governance in relation to the operation of urban services in developing countries. Habitat International, v.21, n.1, p.65-77, 1997.

HUNTER, S. and LEYDEN, K. M. Beyond NIMBY: Explaining Opposition to Hazardous Waste Facilities. Policy Studies Journal, v.23, n.4, p.601, 1995.

IZAZOLA, H., MARTÍNEZ, C. ET $A L$. Environmental Perceptions, social class and demographic change in México City: a comparative approach. Environment and Urbanization, v.10, n.1, p.107-118, 1998.

JACOBI, P. R. Households and environment in the city of São Paulo; problems, perceptions and solutions. Environment and Urbanization, v.6, n.2, p.87-110, 1994.

JAMISON, A. The making of green knowledge: the contribution from activism. Futures, v.35, n.7, p.703, 2003.

KOUSIS, M. Competing Claims in Local Environmental Conflicts in Southern Europe. In: Environmental Politics in Southern Europe, M. K. Klaus Eder (Ed.), Kluwer Academic Publishers, 2001. Cap. 5, p.129- 150 .

KOUSIS, M. Local environmental protest in Greece, 1974-94: exploring the political dimension, Environmental Politics, Taylor \& Francis, Vol. 16, No. 5, 785-804, 2007.

KRAFT, M. E. E B. B. CLARY. Citizen participation and the NIMBY syndrome. Public response to radioactive waste disposal. Western Political Quarterly, v.44, n.2, p.299, 1991.

MARANS, R. W. Understanding environmental quality through quality of life studies: the 2001 DAS and its use of subjective and objective indicators. Landscape and Urban Planning, v.65, n.1-2, p.7383, 2003. 
MARTÍN-CRESPO, M. M. Por qué sí y por que no en mi pátio de atrás - Una revisión del concepto del síndrome «NIMBY» (Not In My BackYard) en torno al tema de la gestión de residuos radioactivos. Politica Y Sociedad, v.23, p.147 - 152, 1996.

NEWMAN, P. The environmental impact of cities. Environment and Urbanization, v.18, n.2, p.275 - 295, 2006.

NUCCI, J. C. Qualidade ambiental e adensamento urbano: um estudo de Ecologia e Planejamento da Paisagem aplicado ao distrito de Santa Cecília (MSP). São Paulo: Humanitas - FFLCH/USP, 2001. 235 p. ISBN 85-7506-017-1.

PACIONE, M. Urban environmental quality and human wellbeing - a social geographical perspective. Landscape and Urban Planning, v.65, n.1-2, p.1930, 2003.

PARKER, G. The role of the consumer-citizen in environmental protest in the 1990s. Space and Polity, v.3, n.1, p.67-83, 1999.

RICHMAN, B. D. Mandating Negotiations to Solve the Nimby Problem: A Creative Regulatory Response. Journal of Environmental Law, v. 20, p. 223-236, 2001.

SAVAN, B., GORE, C. ET AL. Shifts in environmental governance in Canada: how are citizen environment groups to respond? Environment and Planning C: Government and Policy, v.22, p.605 - 619, 2004.

SCHIVELY, C. Understanding the NIMBY and LULU Phenomena: Reassessing Our Knowledge Base and Informing Future Research. Journal of Planning Literature, v.21, p.255-266, 2007.

UNEP. The Global Environment Outlook 3. London: Earthscan Publications Ltd, 2002, ISSN: 1366-8080.

VAN KAMP, I., LEIDELMEIJER, K. ET AL. Urban environmental quality and human well-being: Towards a conceptual framework and demarcation of concepts; a literature study. Landscape and Urban Planning, v.65, n.1-2, p.5-18, 2003.

Sociedade \& Natureza, Uberlândia, 21 (1): 51-70, ABR. 2009 